\title{
PERINGATAN DINI MASA STUDI DAN IPK MAHASISWA BERBASIS FRAMEWORK FOR APPLICATION OF SYSTEM THINKING
}

\author{
Nurjayadi $^{1)}$, Khusaeri Andesa ${ }^{2)}$, Torkis Nasution ${ }^{3)}$, Herwin ${ }^{4)}$, \\ 1,2,4Prodi Manajemen Informatika, STMIK Amik Riau, Jl. Purwodadi Indah KM. 10 \\ email: nurjayadi@sar.ac.id ${ }^{1)}$,khusaeri_andesa@sar.ac.id²), herwin@sar.ac.id $\left.{ }^{4}\right)$ \\ ${ }^{3}$ Prodi Teknik Informatika, STMIK Amik Riau, Jl. Purwodadi Indah KM. 10 \\ email: torkisnasution@sar.ac.id
}

\begin{abstract}
Universities must graduate students according to the curriculum that has been prepared, no later than 14 semesters, if they cannot be fulfilled, students must drop out. Based on graduation data for the last 3 years data on the number of graduations on time was found to be $60 \%$. This means that this will reduce the achievements set out in the 2015-2020 Strategic Plan. If there is no structured and systematic effort, then there is the potential for graduation with an uncontrolled study period. Unfortunately, until now the system that has been built by PT has not been optimal can encourage students to graduate on time. Attempts to achieve timely graduation can be done by involving all lecturers, students, and academic implementing elements to monitor the academic track record of students since being registered as students. Monitoring of the student's academic track record includes attendance, independent assignments, structured assignments, practical assignments, library visits, consultations with PA, IP, and GPA lecturers. The results of supervision are measured at the minimum standard that must be achieved, by connecting all existing variables it can be concluded that the student can pass on time. The purpose of this study is to identify student track records, to connect with minimum standards that must be achieved, to conduct systems-based analysis so that an estimate of graduation performance is generated. Applications that will be generated are based on Framework for Application of System Thinking (FAST) that is good enough to provide early warning to students to graduate on time, and can monitor and monitor the value of discipline so as to prevent academic violations that affect the study period. FAST can analyze existing problems and can design the system. FAST has eight stages, where the first five stages are the stages of system analysis and the next three stages are the design stages. Applications are supported by means to disseminate information quickly and precisely, to fulfill it, use SMS and email as a medium to transmit information from the system to students and academic advisers. If this application is implemented, it can give a warning to students before academic sanctions are issued.
\end{abstract}

Keywords: FAST, study period, graduating on time, early warning

Abstrak

Pemenuhan aturan akademik dan capaian minimal oleh mahasiswa menjadi tolok ukur dan aspek yang menentukan untuk memasuki semester berikutnya. Sistem peringatan dini berupa potensi sanksi, meruakan instrumen monitoring mahasiswa tetap disiplin dan mencegah terjadi potensi masalah. Sehingga mahasiswa terpicu untuk mencapai prestasi akademik yang lebih baik. Setiap Perguruan Tinggi wajib meluluskan mahasiswa sesuai dengan kurikulum yang telah disusun, selambat-lambatnya 14 semester, bilamana tidak dapat dipenuhi, maka mahasiswa harus drop out. Sistem peringatan dini berupa sanksi akademik dapat membantu mahasiswa dan dosen wali untuk mengontrol dan memonitor nilai kedisiplinan sehingga mencegah pelanggaran-pelanggaran akademik sampai dikeluarkan sanksi akademik. Pengembangan sistem informasi ini menggunakan 
Framework for Application of System Thinking (FAST) yang cukup fleksibel untuk menyelesaikan berbagai tipe proyek dan strategi. FAST merupakan framework yang dapat menganalisa masalahmasalah yang ada serta dalam melakukan perancangan sistem. FAST memiliki delapan tahapan, dimana lima tahapan pertama merupakan tahapan analisis sistem dan tiga tahapan selanjutnya merupakan tahapan desain. Sistem informasi yang baik harus didukung sarana untuk menyebarkan informasi secara cepat dan tepat, untuk memenuhinya maka digunakan SMS sebagai media penerus informasi dari sistem ke pengguna. Sistem telah diujicoba dengan data kedisiplinan mahasiswa STMIK Amik Riau. Hasil yang didapatkan sistem dapat memberikan peringatan kepada mahasiswa sebelum dikeluarkan sanksi akademik.

\section{Kata Kunci: FAST, masa studi, lulus tepat waktu, peringatan dini}

\section{PENDAHULUAN}

Sistem peringatan dini (Early Warning System) merupakan rangkaian sistem untuk memberitahukan akan timbulnya sebuah kejadian. Kejadian tersebut dapat berupa bencana maupun tanda-tanda kondisi lainnya. Peringatan dini dapat berupa (Saviano et al., 2016) tindakan memberikan informasi dengan bahasa yang mudah dicerna. Peringatan dini dalam keadaan kritis secara umum merupakan penyampaian informasi yang diwujudkan dalam bentuk sirine, kentongan dan lain sebagainya. Sistem peringatan dini dalam penelitian ini, adalah penerima informasi dapat merespon informasi tersebut dengan cepat dan tepat. Sistem peringatan dini dapat memicu perhatian awal yang diperlukan dan menghindarkan beberapa pontensi kelulusan melebihi batas waktu atau drop out secara tepat dari seluruh indikator drop out para mahasiswa (Christin Nandari Dengen, Kusrini, 2019). STMIK Amik Riau merupakan perguruan tinggi yang menyelenggarakan pendidikan terapan dalam sejumlah bidang pengetahuan khusus. STMIK Amik Riau menyelenggarakan pendidikan kelimuan dalam sejumlah bidang pengetahuan khusus. Sekolah Tinggi adalah (Peraturan Menteri Riset, Teknologi, Dan Pendidikan Tinggi Republik Indonesia, 2015) pendidikan tinggi yang diarahkan pada penguasaan keahlian terapan tertentu, yang mencakup Program Studi Teknik Informatika, Program Studi Sistem Informasi, Program Studi Teknologi Informasi, dan Program Studi Manajemen Inforamtika. Kurikulum pendidikan tinggi merupakan rencana dan pengaturan pendidikan yang terdiri atas standar kompetensi, standar materi, indikator pencapaian, strategi pengajaran, cara penilaian dan pedoman lainnya yang relevan untuk mencapai kompetensi pendidikan tinggi. Nilai indeks prestasi (IP) tiap semester menjadi salah satu faktor yang menentukan apakah mahasiswa tersebut dapat melanjutkan ke semester berikutnya atau tidak (drop out). Selain indeks prestasi, (Himawan et al., 2016) kedisiplinan juga dijadikan tolak ukur yang dinilai keberhasilannya dalam studi mahasiswa STMIK Amik Riau. Sekolah Tinggi menerapkan kedisiplinan yang sangat ketat sebagai pembinaan pembentukan watak, dan kepribadian yang diharapkan dapat meningkatkan kemampuan akademik mahasiswa. Penilaian kedisiplinan meliputi (Cahyo, 2018) kedisiplinan pelaksanaan kuliah dan praktikum, kedisiplinan kegiatan mahasiswa, norma-norma akademik dan perilaku mahasiswa di lingkungan kampus. Pelanggaran kedisiplinan oleh mahasiswa dapat berakibat dikeluarkan sanksi akademik kepada mahasiswa. Sanksi akademik yang diterbitkan berupa peringatan lisan tercatat, surat peringatan pertama, kedua, ketiga sampai pemberhentian sebagai mahasiswa atau Drop Out (DO).

Pembinaan kedisiplinan kepada mahasiswa dilakukan (Salmu, S. \& Solichin, 2017) dalam proses perwalian oleh dosen wali. Dosen wali memiliki kewenangan dalam mengawasi, mencatat, menilai, memberikan pembinaan dan merekomendasikan sanksi 
akademik bagi mahasiswa. Dosen wali melakukan perekapan terhadap data kedisiplinan yang berupa absen perkuliahan dan pelanggaran akademik yang dilakukan mahasiswa pada periode tertentu, kemudian data tersebut diserahkan kepada program studi. Data kedisiplinan tersebut akan dijadikan acuan sanksi akademik kepada mahasiswa. Dosen wali biasanya melakukan pembinaan kepada mahasiswa setelah sanksi akademik diterbitkan. Pembinaan kedisiplinan akan jauh lebih efektif jika dilakukan sebelum sanksi akademik ditebitkan untuk mencegah dikeluarkannya sanksi tersebut, oleh sebab itu diperlukan sebuah sistem yang dapat menginformasikan data kedisiplinan dan memberikan peringatan dini sebelum sanksi akademik dikeluarkan.

Framework for Application of System Thinking (FAST) merupakan metode pengembangan sistem informasi yang cukup fleksibel untuk menyelesaikan berbagai tipe proyek dan strategi (Karnila \& Komputer, 2016). FAST sangat membantu menganalisa masalah-masalah yang ada serta dalam melakukan perancangan sistem. Metodologi FAST memiliki delapan tahapan, dimana lima tahapan pertama merupakan tahapan analisis sistem dan tiga tahapan selanjutnya merupakan tahapan desain. Sebuah sistem informasi harus memiliki kecepatan dan keakuratan dalam pengiriman data, sehingga dapat segera ditanggapi oleh penerima data. Short Massage Service (SMS) adalah salah satu layanan operator seluler yang berupa pesan yang dapat dikirimkan kapan pun dan dimanapun selama dalam jangkauan operator layanan seluler. SMS dapat dijadikan sebagai salah satu sarana untuk pengiriman data sebuah sistem informasi. Data nilai kedisiplinan dan peringatan dini sanksi akademik dapat diberikan mahasiswa melalui layanan SMS kepada mahasiswa dan dosen wali. Dosen wali akan mendapatkan informasi mahasiswa yang memiliki nilai kedisiplinan mendekati diterbitkan sanksi akademik, sehingga dapat melakukan pembinaan kepada mahasiswa untuk meningkatkan kedisiplinan guna mencegah keluarnya sanksi akademik.

Menghasilkan sebuah aplikasi sistem peringatan dini sanksi akademik mahasiswa Sekolah Tinggi menggunakan FAST pada sistem informasi program studi untuk memonitor kedisiplinan mahasiswa dan peringatan dini sanksi akademik berbasis SMS. Capaian tujuan akan memberikan manfaat untuk memonitor perkembangan nilai kedisiplinan mahasiswa dengan baik dan persentase lulus tepat waktu. Dapat digunakan untuk mengurangi sanksi akademik akibat indisipliner dan meningkatkan kedisiplinan mahasiswa. Penyelenggara pendidikan memiliki pendokumentasian dan pengambilan keputusan secara cepat dan tepat dalam pembinaan dan pemberian sanksi akademik.

\section{PENELITIAN SEBELUMNYA}

Terdapat beberapa penelitian yang mendasari penelitian masalah sistem peringatan dini dan membangun sistem informasi perusahaan atau organisasi. Beberapa sistem pendeteksi dini yang dirancang untuk memantau kondisi ekonomi atau keuangan, mengembangkan Early Warning System (EWS) dengan hipotesis krisis yang berbeda yang mungkin timbul dari ketidakstabilan pasar finansial jangka pendek tanpa adanya penurunan fundamental ekonomi jangka panjang (Ady et al., 2020). Analisis sistem sebagai pemecahan masalah teknik yang menguraikan sistem menjadi potongan-potongan komponen untuk tujuan mempelajari seberapa baik bagian-bagian komponen bekerja dan berinteraksi untuk mencapai tujuan mereka. Ini adalah prasyarat untuk merancang sistem, spesifikasi sistem baru dan lebih baik. Definisi analisis sistem dinyatakan sebelumnya telah bergeser dari klasik ke kontemporer definisi lebih. Analisis Sistem adalah istilah yang secara kolektif menggambarkan tahapan analisis dalam konteks rute klasik lengkap untuk FAST 
metodologi yang terdiri dari delapan langkah (Gamble et al., 2017). Langkah kelima pertama adalah tahapan analisis sistem, sedangkan langkah selanjutnya adalah tahap desain (Yasir, 2008). Lembaga-lembaga pendidikan tinggi bisa memanfaatkan kekuatan prediksi Learning Management System (LMS) data untuk mengembangkan alat pelaporan yang mengidentifikasi berisiko mahasiswa dan memungkinkan untuk lebih pedagogis intervensi tepat waktu. Makalah ini menegaskan dan memperluas proposisi ini dengan menyediakan data dari sebuah proyek penelitian internasional menyelidiki kegiatan mahasiswa yang akurat secara online memprediksi prestasi akademik. Analisis data LMS pelacakan dari Blackboard Vista didukung Tentu saja mengidentifikasi 15 variabel menunjuk-kan korelasi sederhana yang signifikan dengan kelas mahasiswa akhir (Jayakrishnan et al., 2018). Pemodelan regresi menghasilkan model yang terbaik sesuai prediksi untuk kursus ini yang mencakup variabel kunci seperti jumlah pesan yang diposting diskusi, jumlah pesan mail yang dikirim, dan total jumlah penilaian selesai dan yang menjelaskan lebih dari $30 \%$ dari variasi dalam kelas mahasiswa akhir. Pemodelan logistik menunjukkan kekuatan prediksi dari model ini, yang diidentifikasi dengan benar $81 \%$ dari mahasiswa yang mencapai nilai gagal. Selain itu, jaringan analisis forum diskusi saja diberikan wawasan ke dalam pengembangan komunitas belajar mahasiswa dengan mengidentifikasi mahasiswa terputus, pola mahasiswa-mahasiswa komunikasi, dan posisi instruktur dalam jaringan. Penelitian ini menegaskan bahwa informasi yang bermakna pedagogis dapat diekstraksi dari LMS yang dihasilkan mahasiswa pelacakan data, dan membahas bagaimana temuan ini menginformasikan pengembangan dashboardlike disesuaikan alat pelaporan untuk pendidik yang akan mengekstrak dan visualisasikan data real-time pada keterlibatan mahasiswa dan kemungkinan sukses (Rasyd et al., 2017).

Penelitian ini focus pasa kecepatan dan keakuratan dalam pengiriman data, sehingga dapat segera ditanggapi oleh penerima data. Media pengiriman yang digunakankan adala Short Massage Service (SMS) dan e-mail. SMS dapat dijadikan sebagai salah satu sarana untuk pengiriman data sebuah sistem informasi. Data nilai kedisiplinan dan peringatan dini sanksi akademik dapat diberikan mahasiswa melalui layanan SMS kepada mahasiswa dan dosen wali. Dosen wali akan mendapatkan informasi mahasiswa yang memiliki nilai kedisiplinan mendekati diterbitkan sanksi akademik, sehingga dapat melakukan pembinaan kepada mahasiswa untuk meningkatkan kedisiplinan guna mencegah keluarnya sanksi akademik.

\section{METODE PENELITIAN}

\subsection{Jenis Penelitian}

Penelitian ini menggunakan metode penelitian tindakan (action research) yaitu metode yang bertujuan untuk mengembangkan keterangan baru untuk meningkatkan kelulusan tepat waktu atau kebutuhan praktis manusia lainnya. Untuk menemukan dasar-dasar dan langkahlangkah yang tepat untuk melakukan tindakan antisipasi secara praktis. Action research dilakukan dalam delapan fase yaitu preliminary investigation phase, problem analysis phase, requirement analysis phase, decision analysis phase, desain phase, construction phase, implementation phase, operation and support stage phase.

\subsection{Pengumpulan Data}

Metode pengumpulan data yang dilakukan pada penelitian ini yaitu : 
Hal : $261-271$

1. Wawancara, di lakukan secara langsung terhadap mahasiswa di Program Studi Teknik Informatika untuk mendapatkan informasi dan data-data yang dibutuhkan dalam peringatan dini lulus tepat waktu untuk menghindari mahasiswa drop out.

2. Observasi, mengadakan pengamatan dan pengumpulan data history berupa data internal dan external yang telah tersusun dalam database maupun kelengkapan data yang di butuhkan.

\subsection{Analisis Data}

Penelitian ini menggunakan framework untuk menganalisis data pada penelitian ini menggunakan Framework for Application of System Thinking (FAST) dengan melakukan tahapan preliminary investigation phase, problem analysis phase, requirement analysis phase, decision analysis phase, desain phase, construction phase, implementation phase, operation and support stage phase. Data yang digunakan untuk penelitian ini adalah data mahasiswa, data evaluasi IP dan IPK mahasiswa, recording data bimbingan dengan Pembimbing Akademik pada Prodi Teknik Informatika, yang bersumber dari BAAK.

\subsection{Tahapan Penelitian}

Penelitian Penelitian dibagi ke dalam 3 bagian pokok (1) penyusunan proposal penelitian; (2) melaksanakan penelitian; (3) diseminasi hasil penelitian.

1. Memuat: studi awal, latar belakang penelitian, tujuan penelitian dan penjelasan, rasional penelitian, metodologi penelitian, hasil dan dampak penelitian, penilaian penelitian

2. Melaksanakan Penelitian, memuat: menentukan populasi dan sampling, menyusun instrumen penelitian, mengumpulkan data, mengolah data, analisa, desain, konstruksi aplikasi, pengujian dengan black box dan white box, implementasi, membahas hasil penelitian, menarik kesimpulan, pengujian aplikasi, implementasi

3. Luaran dan Laporan Penelitian, memuat: menyiapkan luaran (artikel ilmiah, submit conference dan poster), manual penggunaan Framework for Application System Thinking, menyiapkan laporan penelitian, dan presentasi hasil penelitian

\subsection{Teknik Analisis}

Miles dan Huberman dalam Sugiyono (2009:246) mengemukakan bahwa aktivitas dalam analisis data kualitatif dilakukan secara interaktif dan berlangsung secara terus-menerus sampai tuntas, sehingga datanya sudah jenuh.

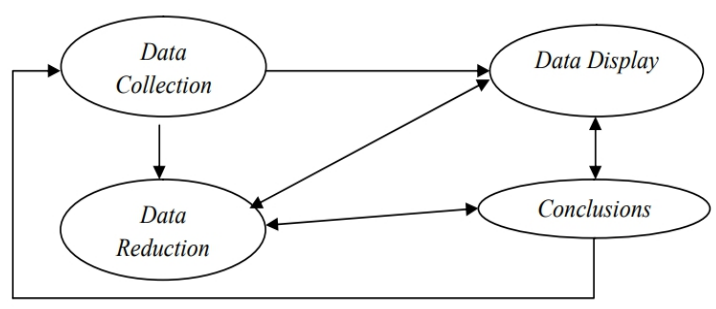

Sumber: Sugiyono (2009:247) 
Analisis data dilakukan dalam suatu proses, pelaksanaannya mulai dilakukan sejak pengumpulan data dan dilakukan secara intensif. Sesudah meninggalkan lapangan, menganalisis data memerlukan usaha pemusatan perhatian, pengarahan tenaga fisik dan pikiran, selain itu peneliti perlu mendalami kepustakaan guna mengkonfirmasi teori baru yang mungkin ditemukan.

\section{HASIL DAN PEMBAHASAN}

\subsection{Pembahasan}

Dari Pada penelitian ini menerapkan metodologi Framework for Application of System Thinking (FAST) yang cukup fleksibel dalam pengembangan sebuah sistem informasi. Pada pembahasan ini peneliti menerapkan metodologi FAST yang tersaji pada gambar 1 .

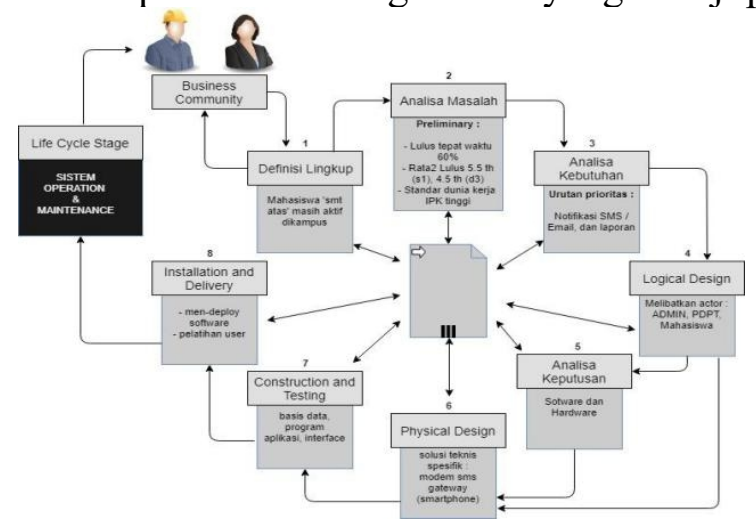

Gambar 1. Blok Diagram Aplikasi Peringatan Dini berbasis FAST

Adapaun langkah atau fase dalam penelitian ini adalah sebagai berikut :

1. Scope Definition (Definisi Lingkup)

Pada tahap awal, peneliti menemukan permasalahan yang dijumpai baik secara langsung maupun tidak langsung seperti masih dijumpai mahasiswa 'semester atas' masih aktif di kampus STMIK Amik Riau yang seharusnya pada perhitungan semester normal sudah menamatkan studinya. Ruang lingkup penelitian ini meliputi: peringatan dini kepada mahasiswa agar lulus tepat waktu, serta menghasilkan laporan yang ditujukan kepada prodi dan dosen PA untuk dijadikan pedoman dalam memimbing mahasiswa.

2. Problem Analysis (Analisa Permasalahan)

Pada tahap ini meneliti masalah-masalah yang muncul pada penelitian sebelumnya serta melakukan Preliminary Investigation kepada bagian terkait

3. Requirements Analysis

Melakukan pengurutan prioritas dari kebutuhan yang diinginkan pengguna berupa data, proses, dan antarmuka.

4. Logical Design (Desain Logis)

Pada tahap ini menjawab pertanyaan-pertanyaan tahap Requirements Analysis (Tahap 3), dari sisi penggunaan teknologi yang akan dibangun pada sistem, yakni paling tidak melibatkan 3 actor yaitu PDPT sebagai bagian entry nilai, Administrator dalam manajemen user, serta mahasiswa yang menerima informasi terkait peringatan dini yang disajikan pada gambar 2 


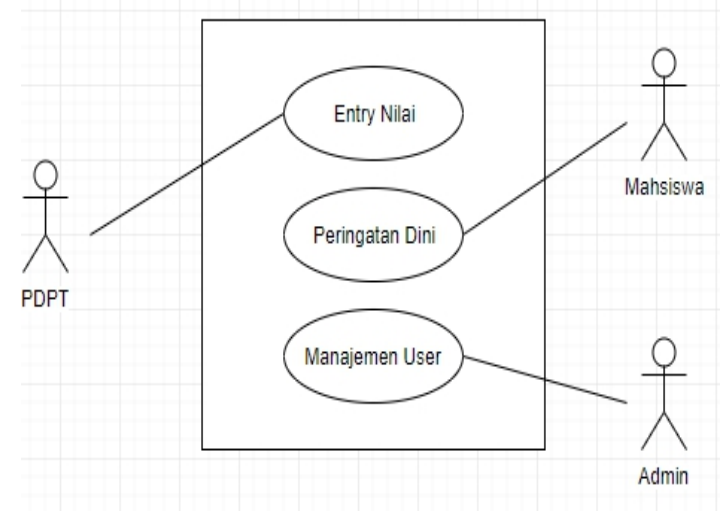

Gambar 2 Use Case Aktor

5. Decision Analysis (Analisa Keputusan)

Pada mempertimbangkan software/ hardware yang akan dipilih dalam implementasi sistem. maka dibutuhkan :

a. Hardware: seperangkat komputer processor minimal dual core, memori: $4 \mathrm{~Gb}$, HDD min $250 \mathrm{gb}$ dan smartphone sebagai modem sms gateway

b. Software : SO Android, Database MySQL, PHP, xampp versi 7.7, Macromedia dreamweaver 8 , Windows 8 dan web browser Mozilla / Chrome.

6. Physical Design \& Integration

Pada fase ini diberikan solusi teknis spesifik yang akan dijadikan sebagai acuan dalam membuat sistem yang akan dikembangkan. Maka diperlukan sebuah smartphone sebagai modem sms gateway yaitu fitur yang dimodifikasi sesuai kebutuhan yang dapat melakukan: Auto Reply, Pengiriman massal (broadcast message), dan dapat melakukan pengiriman terjadwal seperti pada gambar 4.3

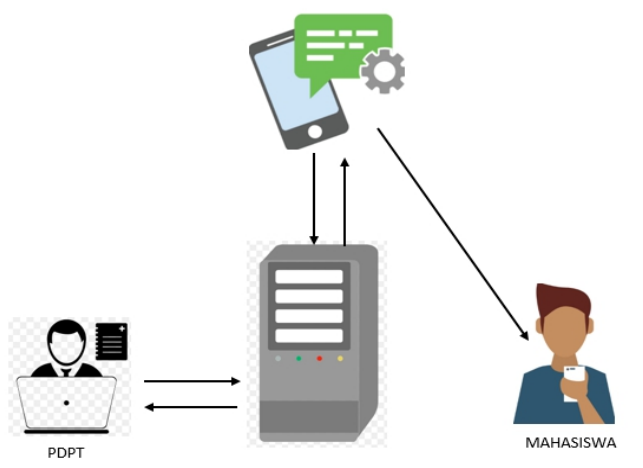

Gambar 3 Physical Design \& Integration

7. Construction \& Testing

Pada fase construction akan dilakukan pembangunan aplikasi peringatan dini yang sesuai dengan rancangan dan deskripsi yang telah dibuat sebelumnya berupa basis data, program aplikasi, serta pembangunan interface. Selanjutnya untuk memastikan sistem yang dihasilkan sesuai dengan spesifikasi maka perlu dilakukan proses testing sebelum implementasi. Pengujian perangkat lunak ini menggunakan metode pengujian black box.

8. Installation \& Delivery 
Pada tahap ini akan dioperasikan sistem yang telah dibangun yang dimulai dengan mendeploy software hingga memberikan pelatihan kepada user mengenai penggunaan sistem yang telah dibangun.

\subsection{Implementasi}

Dari Implementasi antar muka menampilkan layar dialog interaksi antara user dengan Aplikasi Peringatan Dini Masa Studi dan IPK mahasiswa berbasis Framework for Application of System Thinking. Layar dialog dirancang secara optimal dan user friendly, sehingga user betah dan tidak bosan selama menggunakan aplikasi. Implementasi antarmuka adalah:

1. Halaman Entri Data

Pada halaman ini bagian PDPT memasukkan nilai sebagai KHS berdasarkan KRS yang telah diambil oleh mahasiswa pada semester aktif.

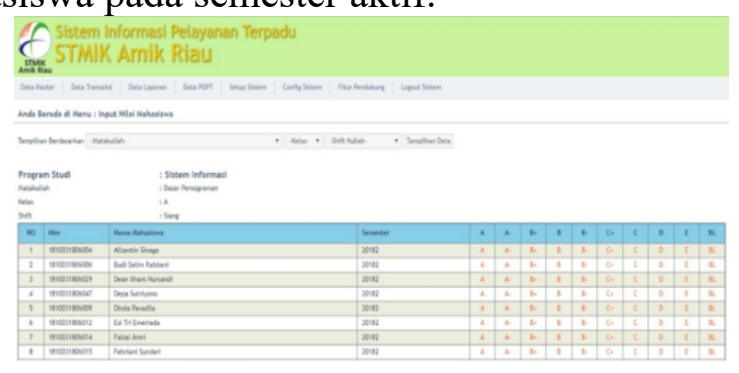

Gambar 4. Halaman entry data nilai

2. Halaman Mahasiswa

IP rendah, adalah halaman data mahasiswa yang memiliki IP dibawah 2.75

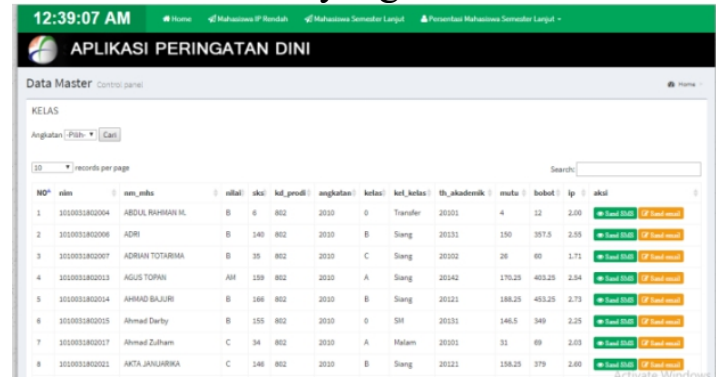

Gambar 5. Halaman mahasiswa IP rendah

3. Halaman semester lanjut

adalah halaman data mahasiswa masa studinya telah lebih dari 4 tahun

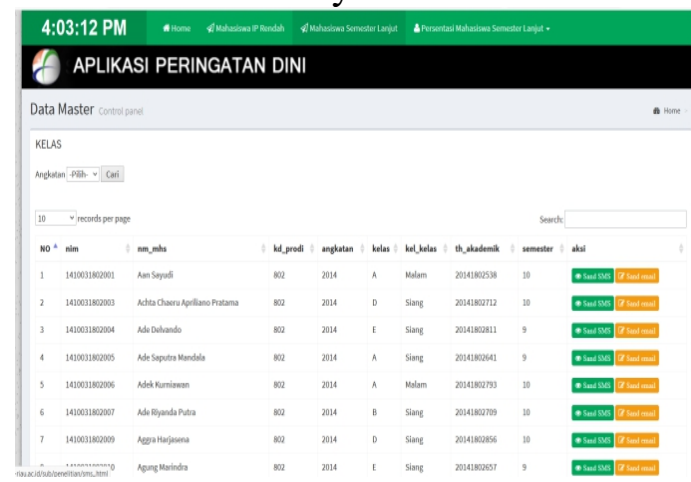


4. Halaman Persentasi kelulusan

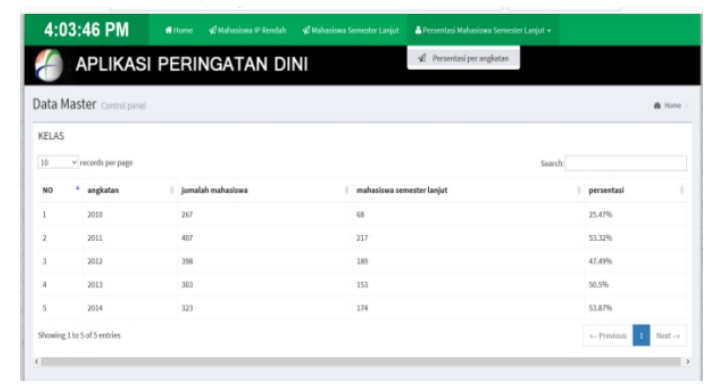

Gambar 7 Persentasi kelulusan

5. Halaman (email dan SMS)

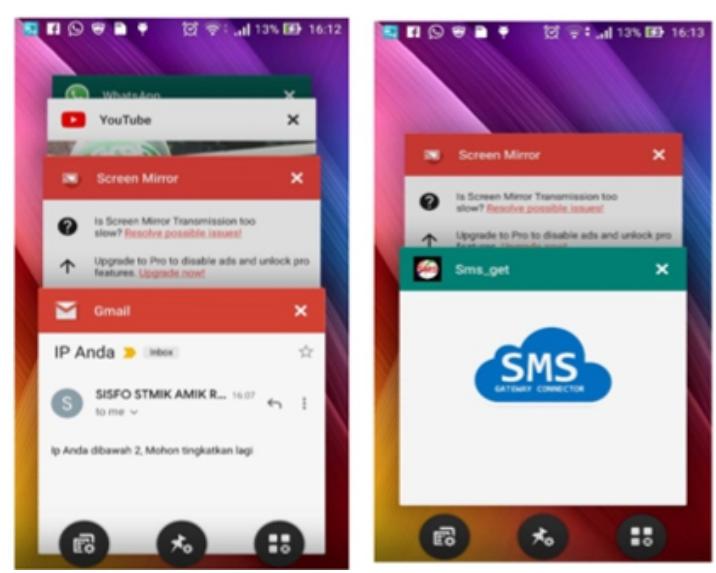

Gambar 8 Halaman Smartphone

\section{PEMBAHASAN}

Faktor Aplikasi Peringatan dini ini telah dikembangkan sesuai dengan tahapan FAST. Tahapan-tahapan yang sudah dilalui yaitu Scope Definition (lingkup definisi) - Problem Analysis (AnalisisPermasalahan)- Requirement Analysis (Analisis Kebutuhan) - Decision Analysis (Analisis Keputusan) - Logical Design (Desain Logis) - physical Design \& Integration (Desain Fisik dan Integrasi) - Construction \& Testing - Installation \& Delivery. Setelah perangkat lunak jadi, peneliti melakukan pengujian dalam rangka melakukan proses verifikasi dan validasi. Adapun proses verifikasi dengan melakukan pengujian unit dengan menggunakan metode white box dan pengujian integrasi dengan menggunakan metode blackbox. Sedangkan proses validasi yaitu dengan melakukan pengujian sistem dengan menggunakan metode stress test dan instability test, kemudian untuk pengujian acceptance test dengan menggunakan metode Mean Opinion Score. 
Tahap implementasi merupakan tahap penerapan sistem yang telah didesain atau dirancang, sehingga sistem yang telah dibuat dapat dioperasikan dan digunakan secara optimal sesuai dengan kebutuhan. Setelah implementasi maka dilakukan pengujian terhadap sistem yang baru dan akan dilihat kekurangan-kekurangan pada aplikasi yang baru untuk pengembangan sistem selanjutnya. Spesifikasi perangkat keras tidak ditentukan secara rinci. Secara umum semua komputer yang dijadikan sebagai server telah memiliki sistem operasi dan telah di instalasi web server berbasis apache. Pada sisi client yang dibutuhkan adalah smartphone yang digunakan untuk menampilkan aplikasi peringatan dini.

\section{SIMPULAN}

Penelitian ini telah selesai dilaksanakan, tersedia aplikasi peringatan dini masa studi dan IPK mahasiswa berbasis Framework for Application of System Thinking. Setelah dilakukan pengujian program dalam bentuk training atas data. Informasi peringatan yang diberikan dalam bentuk pendukung keputusan, eksekusi atas status mahasiswa sepenuhnya dalam kewenangan pegawai bersangkutan. Pesan disampaikan kepada mahasiswa, sedangkan laporan disampai-kan kepada pembimbing akademik, dan ketua prodi. Diperlukan tekad dan komitmen yang kuat dari seluruh sivitas dan tenaga kependidikan untuk mendukung mahasiswa tamat tepat waktu.

\section{UCAPAN TERIMAKASIH}

Ucapan terima kasih kepada LPPM STMIK Amik Riau dan Ketua STMIK Amik Riau yang telah membantu dalam pelaksanaan penelitian baik baik moril maupun pendanaan.

\section{DAFTAR PUSTAKA}

Ady, S. U., Tyas, A. M., Farida, I., \& Gunawan, A. W. (2020). Immediate and Expected Emotions Toward Stock Returns Through Overconfidence and Cognitive Dissonance : the Study Of Indonesian Investor Behavior. PalArc's Journal of Arcaeology of Egypt, $17(3), 1140-1165$.

Cahyo, P. W. (2018). Klasterisasi Tipe Pembelajar Sebagai Parameter Evaluasi Kualitas Pendidikan Di Perguruan Tinggi. Teknomatika, 11(1), 49-55.

Christin Nandari Dengen, Kusrini, E. T. L. (2019). Penentuan Association Rule Pada Kelulusan Mahasiswa Menggunakan Algoritma Apriori. Jurti, 3(1), 20-29. https://core.ac.uk/download/pdf/268075092.pdf

Gamble, E., Parry-Strong, A., Coppell, K. J., McBain, L., Bingham, L. J., Dutton, L., TapuTa'ala, S., Smith, R. B. W., Howells, J., Metekingi, H., \& Krebs, J. D. (2017). Development of a structured diabetes self-management education program specific to the cultural and ethnic population of New Zealand. Nutrition and Dietetics, 74(4), 415422. https://doi.org/10.1111/1747-0080.12148

Himawan, H., Cahyadi, D., \& Munawati, M. (2016). Prototype Sistem Informasi Perhitungan Nilai Poin Pelanggaran Tata Tertib Pada Smk Yuppentek 1 Tangerang. CCIT Journal, 9(3), 336-343. https://doi.org/10.33050/ccit.v9i3.470

Jayakrishnan, M. A. L., Bin Mohamad, A. K., \& Yusof, M. B. M. (2018). The holistic view of business intelligence (BI) and big data analytics (BDA) towards designing strategic performance management framework: A case study. Journal of Theoretical and Applied Information Technology, 96(7), 2025-2045.

Karnila, S., \& Komputer, F. I. (2016). Perancangan aplikasi berbasis knowledge 
Management untuk memonitoring prestasi akademik ini difasilitasi interface berupa Aplikasi yang digunakan oleh bagian pengelola. 16(2), 150-159.

Rasyd, R. F., Pradana, F., \& Priyambadha, B. (2017). PeringantanDini.pdf. Pengembangan Teknologi Informasi Dan Ilmu Komputer, 1(11), 20-36.

Peraturan Menteri Riset, Teknologi, Dan Pendidikan Tinggi Republik Indonesia, 1 Current Science 1 (2015).

Salmu, S., D., \& Solichin, A. (2017). Prediksi Tingkat Kelulusan Mahasiswa Tepat Waktu Menggunakan Naïve Bayes : Studi Kasus UIN Syarif Hidayatullah Jakarta Prediction of Timeliness Graduation of Students Using Naïve Bayes : A Case Study at Islamic State University Syarif Hidayatullah Jakarta. Prosiding Seminar Nasional Multidisiplin Ilmu, April, 701-709.

Saviano, M., Polese, F., \& Walletzký, L. (2016). A T-shaped model for rethinking higher education programs. 32(September 2016), 425-440. 